cows, investigations on the chemical composition of typical milk and of taints of milk, the lactic acid bacteria and cheese-ripening studies, and on pasteurization and tubercle bacilli in milk. Cases of contagious abortion among the Institute's herd of cows gave an opportunity for investigating Brucella abortus infection. Bacteriological testing of milk samples and market milk investigations have also been carried out, and the phosphatase test for efficiency of pasteurization has been re-examined. The financial condition of the Institute is considered, and an appeal is made for further funds to enable an extension of the work to be made.

\section{Oxford and Present Needs in Science}

Referring to the leading article in NATure of February 20 under this title, a correspondent writes as follows: "As some readers may not be familiar with the names given to certain buildings in Oxford, it may be helpful to state that the 'Ashmolean Museum' now means the Museum of Art and Archæology, chiefly classical, established in Beaumont Street in 1890, whereas the 'Museum of the History of Science' means the ancient scientific collections in the Old Ashmolean Building, which was the only science museum from 1683 until 1860. In this building Ashmole's old museum room is now full to overflowing of historic instruments and specimens; and money is needed for its extension. The changes contemplated in the various scientific departments of the University make it more than ever necessary to provide for the preservation of things of historic value that might otherwise be scrapped".

\section{Early Man in Minnesota}

Prof. A. E. Jenks, of the University of Minnesota, reporting recently on "Minnesota man", a female skeleton found in ancient lake deposits in 1931, attributes to it an age of approximately 20,000 years, and regards it as the oldest specimen of early man to be found in America. The teeth had all erupted, with the exception of the wisdom teeth, but as the long bones appear to be still immature, the age of the girl was probably about fifteen years. The teeth are larger than normal in prehistoric man. In summing up the characters of the skeleton, Prof. Jenks, it is stated by Science Service, regards it as Homo sapiens, of an early type of evolving Mongoloid, forecasting the aboriginal American, especially the Eskimo, rather than the modern Mongol. It has been computed that the Lake Pelican deposits, in which the skeletal remains were found, antedata those of the glacial Lake Agasiz by some two thousand years, thus warranting this increase in the age usually admitted for early man on the American continent.

\section{Sanitary Aviation in Soviet Russia}

THE sanitary aviation service maintained by the Red Cross and Red Crescent Society of the U.S.S.R. is fast becoming a regular institution for medical aid, particularly in outlying regions of the Union. Sanitary aeroplanes are kept in readiness in all parts of the Union to answer urgent calls for medical aid. In
1936, more than 400 patients were carried by air to hospitals and more than 500 specialists were taken by air to various places where they performed some fifty major operations and treated about four thousand seriously ill persons. In 1936 also, the sanitary aeroplanes of the Red Cross and Red Crescent Society carried more than 2,000 kilograms of medical supplies to different points of the Union.

\section{Biochemistry in the U.S.S.R.}

WE have received the first five numbers of the first volume of a new Russian journal, devoted to biochemistry. It is entitled Biochimia, and is edited by A. N. Bach and W. A. Engelhardt. The papers are in Russian, but each is provided with a summary in English or German. The average size of each number is about 120 pages. The papers deal with work on vitamins, enzymes and other biochemical problems. The journal should enable workers in other countries to gain some idea of the work which is being carried out in Russia in biochemistry.

\section{Comets}

A New comet was discovered by Dr. F. L. Whipple at Harvard on February 7 . Its magnitude was 12 at the time of discovery, and it was described as diffuse with a central condensation, and a tail less than $1^{\circ}$ in length. Dr. Whipple computed the following parabolic orbit :

$$
\begin{array}{crr|r}
T 1937 & \text { Jan. } & 22 \cdot 070 & \text { U.T. } \\
\omega & 111^{\circ} & 27^{\prime} & \\
\Omega & 127 & 4 & 1937 \cdot 0 \\
i & 41 & 4 & \\
q & 1 \cdot 6610 & &
\end{array}
$$

It is now about 1.5 units from the earth, which it is approaching, but it is not likely to become a con. spicuous object. Mr. Simizi in Japan detected Daniel's Comet, $1909 \mathrm{iv}, 1937 a$, on January 31. Its magnitude was 13 and it was diffuse without any central condensation. Mr. Hirose computed an orbit the elements of which are given below. It is receding from the earth, and is now more than 1.4 units distant.

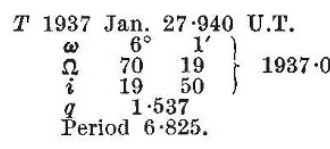

\section{The Night Sky in March}

During March, the duration of night in the latitude of London decreases by nearly two hours. On March $21^{\mathrm{d}} 1^{\mathrm{h}}$ the sun enters the sign Aries (Spring Equinox). The moon is new on March $12^{\mathrm{d}} 19 \cdot 5^{\mathrm{h}}$ and full on March $26^{\mathrm{d}} 23 \cdot 2^{\mathrm{h}}$. No bright stars are occulted during the month, but the following disappearances may be noted : 108 Tauri (mag. $6 \cdot 2$ ) on March $18^{\mathrm{d}} 19^{\mathrm{h}} 39 \cdot 0^{\mathrm{m}}$ when the moon is 6 days old, and $e$ Leonis (mag. $5 \cdot 1$ ) on March $25^{\mathrm{d}} 21^{\mathrm{h}} 54 \cdot 4^{\mathrm{m}}$, the moon being 13 days old. The planet Venus, which does not set until about $22^{\mathrm{h}}$, is a striking object and reaches its greatest brilliancy on March 12; the area of the illuminated crescent is then $0 \cdot 28$ that of the whole apparent disk. Mercury, being in superior conjunction with the sun 